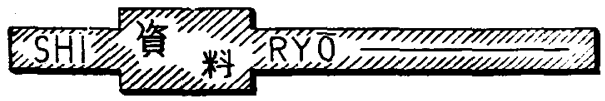

\title{
貿易自由化と化学工業
}

$$
\text { 大島 竹 治* }
$$

Liberalization of Trade in Japan Chemical Industries

\section{Takeji Oshima}

\section{I. は し がき}

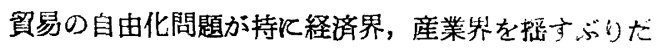
してからもう相当の時日を経過した。堂々としたるが如 くして，実は中味の空虚な議論も，また一方的かつ極端 な自己防衛的議論も一応は出つくし，この問題をめぐる 裳識も一応かたまりつつあるか机見える。

政府では，去る6月末，貿易為替自由化計画り大綱を 発表したが，部分的には多少遠慮しているところもある が，産業人の常識からみて概柇当を得ているように思わ れる。

元来, 貿易の自由化は産業人のモットーであらねばな らない。今日アウタルキー的な考え方に立脚した自由化 反対論は日本のように多くの生産資材原料を自給できな い国では，自滅とまで行かなくとも，少なくとも生活程 度の停带を意琼し，議論の対象とはならないと考える。 またこういう考方方は一方からみると産業人が自己の立 場飞安定せんとする横着な考え方が根底をなしている場 合か多い。しかしこれはひとり産業人のみならず䥀融 界々てき同様で自由化をモット一とすへきもりと思う。 貿易の自由化などということは至極当然のことであって 少しす異とするに足らない。しかしながら，現実の問題 としては，戦後ながらく日本は貿易鎖国的な空気，温床 にあったのであるから, これに急に世界の荒波, 暴風を あてたならは産業は忽ち枯死してしまうかもしれ奴。問 通仕自由化する順序とその時期沉あるのである。それは 植物を育てる場合と同しことであろう。

しからぼ化学工業の貿易自由化はどういう順序でな るべきでろろか。それにはまずこの問題をめぐる一般 的な要素について検討してから考えられねばならないこ とであろう。以下一般情勢とともに私の心中を往来する 所信を少しく述へさせてもらいたいと思う。

\section{II. 貿易自由化に関する諸要素について}

貿易の自由化関連して考慮すべきいくつかの重要な

*日本化学工業協会（東京都千代田区舵ヶ関 3-4）
問題はあるが，方の主要なるあのについて現在の情勢と ともと一般的な所見を述べればまずその第 1 は

1. 時期の問題 政府では初め 3 年, 後になって 5 年といい, 諸説まちまちであったが, まあ5年完了, 一 応の目標を 3 年に抢くというくらいが，まず稳当なとこ ろであろうと思う。ともかく船が荒海出ようというの である。それにはいろいるの準備とトレーニングがいる のだ。これから船がはじめて大海に出て安全に航海しよ うというのである:あくまで慎重であらねばならないで あろう。

2. 金利の問題 政拊で作った大綱汭，貿易自由 化の準储工作としての問題佰関税改訂, 企業合理化, 金利の問題をあけている。金利については若干遠慮した 言い方をしているるが，このほか㛐重要な事項として独禁 法の問題と技術導入の問題がある。周知のようK日本で は工業家が借入れる資金の金利は至極高い。金利という あのは後進国ほど高いのを普通とするが，一流国で日本 ほど金利の高い国はない。もし “貿易の自由化が出来 ないのは，産業家が一人前でないということだ”と言 う人があるなら（そういうことを言う学者先生は多いの たが）金利が一流国並みでないことは，金融業界が一人 前でないことを意味する，産業は一国の各部門の綜合芸 術である。金利が外国より高く，原料は外国から輸入 乙, 電力, 石炭も外国より高く(安いのは鉄道運貨ぐら いなものだ。それに給料がまだ少し安い)，乙かもその 製品はとにもかくにも世界一流国に伍して互角の勝負を しつつ, 世界各国に進出しているのである。日本の産業 家が目下各国注目の的であり, 酕敬をうけつつあるのは 当然というものであろう。

とあかく金利引き下げに政府, 民間当事者が先ず第一 そ努力することは自由化の重要なポイントであらねばな らない。産業家はこれまで金融業者から金利の下げら れないのは，預金利子を下けなければならないからだと 常に聞かされてきている。しかると今日では，国債であ れ，電力株であれ，銀行預金利子よりはるかに高い金利 の保証された有価証券がたくさんあるのである。しかし 
ながら金融業界では金利引下げの問題をタブーにしてい るか沉える。この遂行はなかなか骨の招れることでは あるが，ぜひやらねばなら最も重要なととであるう。

3. 関税定率の改訂 現行の 関税定率は, 昭和 26 年 5 月と改訂されたものだが，これは当時 G.H.Qの 制限下にあったので，低関税をしいられた傾向があるの は事実であるが，化学工業䏓ついてみ和，外国比し てそう低関税であったわけではない。それにバランスが 比較的よくとれていることで，今日はなはだ評利がよ い。この改訂は業界が原案を作り, 通産, 大藏, 安本, と協議して作ったのであるが，原案作成者の一人として 筆者もはなはだ得意なのである。今その主だったものを 例汒々って化学製品の英, 米, 独と日本の関税率を此較 すると表 1 の如くである。

表 1 主要化学製品諸国関税率

\begin{tabular}{|c|c|c|c|c|c|}
\hline & 日本 & 米国 & 西 & 英 & 仏国 \\
\hline カセイソーダ & $20^{\%}$ & per $\mathrm{lb}_{1 / 2 \varnothing}$ & $9^{\%}$ & $10 \%$ & $20^{\%}$ \\
\hline ソ - ダ 灰 & 25 & per $1 \mathrm{~b}$ & 9 & 10 & 25 \\
\hline ベンゾール & 5 & Free & $\begin{array}{l}\text { per } 100 \mathrm{~kg} \\
16.40 \mathrm{D} . \mathrm{M}\end{array}$ & $\begin{array}{c}\text { Per gallon } \\
0-2-6\end{array}$ & 20 \\
\hline$\supset \pm,-U$ & 20 & $\begin{array}{l}\% \text { per lb } \\
20+3^{1} / 2 \varnothing\end{array}$ & Free & 10 & 25 \\
\hline カーバィト & 20 & ${ }^{\text {per lb }} 1 \varnothing$ & 11 & Free & 30 \\
\hline 硫 & 20 & Free & Free & 10 & 10 \\
\hline 酸 & 20 & Free & 6 & 10 & 18 \\
\hline
\end{tabular}

者はすでに尊入しているのて競争者の出ること恐れ， また過当競争を恐れて(これらは本質的には自己の防街 のためなのだが）またある者は技術家の軽視，研究機関 の無視を慮して，またさらに人にょってはこのくらい 制限してもこうだから，制限しなかったらどのくらい出 るかわからなというであるう。乙かしながら制限し て，あるいは先着順の如く，あるいは許可以期限のある 如くいわれるからこそ，今やろうと思わなくても今の中 に権利だけはとって括こうとぼかり，わんさと押しかけ るのである。いつでも自由にやんなさいといったら、そ う余計に申し出るとは，私は考党ない(人の成功するか 否かを確かめてからやる人も出るであろう)。工業家注 概ね決して馬鹿なのではない。多額の金をつぎこむのに 採算，力量を無視してまでやろうとする人は，そうある とは考兄られない。

今, 欧米一流国淿行って技術導入の話 をしたら，それは何のことかといわれる だろう。試みに技術の本山のごとくいわ れている西ドイツのへキスト行ったと 考壳てごらんなさい。たとえは石油化学 の部門を尋ねたとする。ここまではI. C. I. の技術，ことまではシュューポン， ここからはサンゴーバンのそれといわれ るでしょう。一体どこがドイツの技術な んですかい......といいたくなである う。ほかの会社に行ったって概ね同梯で

しかしながら当時相当先を考劣て原案を作ったつもり ではあったが，それから大分時がたっている。したがっ て事情の変ったものも相当にあるので, 自由化するとな ると相当修正すべき個所が出てきている（目下検討中で ある)。さらにこれと関して最も重要なことはダンピン グに備えて, 緊急条項, タリフコーター制, 弾力関税を 法制化することである。目下政府は次の通常国会で, 関 税改訂をやりあけてしまうつもりでいるようであるが， 二, 三年はかかるであろう。その時の事情とその後の事 情とを合わぬ考えると, 関税率は概ね現行通り。特別事 情のあのが 5 10\% あがるというくらいが括ちである うと思われる。国際比価 (価格差) から関税を 100 15 ○\%にせよという業界む出ているが，これは識喤から はとりあわれないであろう。ただ，祭急条項の法制下だ けは，ぜひともやらねはならないと思うし，目下政拊当 局もとう考えている。

4. 技術導入の問題 技術導入は自由にすべとい ったら, 政府筋ばかりでなく, 現在化学工業々界です相 当珙論のある人があるのであろうと思われる。このある．
ある。今日どこの国へ行っても自国の研究だけで世界の 先頭を維持できると考えている者はないであるう。事 実，欧米各国の各社は，今使わないパテントをやたらに 外国から買っている。またそうでなくては世界を相手汇 摬争していけないであろう。これは私自身の技術家とし ての過去の経過からであるが，技術は思いきって外国か ら買い，技術家はその先を外国と競争して研究していく のが本筋であろうと思う。技術の進歩は無限であり, 一 方ビジネスにはタイムというととが重大なファクターだ からにはかならない。一方研究は技術を買うとととは别 K, 不断の努力と国家の助成がぜひとも必要なととと思 う。技術を買うことと重複しても一向さしつかえない。 また決して損にはならない。技術を買っても下地がなく てはそう早くマスターできるすのではないし，ましてや 続いてその上を行くことなんぞはなかなかでるあので はない。技術導入は機会均等たるへく，また欧米のごと く自由にして，国として決して䭫失はないものと考觉 る。

5. 独禁法の問题 今一つ自由化の問題にからんで 
独禁法の停止がよく叫ばれている。つまり業者カルテル を許せということである。業者カルテルについてはすで 水いいろな場合梳いいるな形で許可されるようにな っているが, なかなか手がかかるもっとも手のかかる 上ラとなっているのる一応の理屈はある。これを悪用し たら国民生活に，また国の将来の動向に大きな悪影響が 起りうる。しかし，だからといって無榎にこの門戸を閉 じょうとする態度す解しか齐る。そこで，ここにての方 針飞大愊な筋が必要であると思う。それには貿易自由化 を行なっている品目については, 業者カルテルは無条件 炕許してよいのではないかということである。いうまで あなくそれは不法な值段でカルテルを協定したら，たち まち海外からの輸入がこれを矯正することになるからに 外ならない。

6. その他 その他, この外位政府その他で常にい われている企業合理化と, 税制上の特別待遇の問題が一 般論としてある訳である。企業合理化とついては，世の 学者先生はよくいわれるが，何をどうしようということ をいわれない。自信ある具体策のない主張は中味のない 重箱のようなむので空念仏にすぎない。業界では合理化 の必要なことは学者先生以上飞よく心得ている。業界で は自由化の挂声だけで十分に緊張して合理化に努力して いるのである。この点では自由化の政府声明は，すでK 目的を達しているのである。要るのはその具体的な方法 と自信なのである。

輸出金融，ならびそ税制上の優待り問題はなかなか時 間がかかる。必要であり,よいことではあるが, 前項の ごとく必須の問題とする訳にはいかないであろう。

以上をむって貿易自由化を巡る諸問題について，一般 情勢と共に私見をのへさせてもらった訳であるが，乙か らは化学工業の自由化はいかなる順序と準備をもって進 めるべきであろうか。

\section{III. 貿易自由化亡化学工業}

\section{(第一次製品から徐々飞 3〜5 年で)}

1. 一般 (i) 日本の化学工業は, その国際的性 格から自由化にはきわめて敏感で, 初めは多少危惧の念 を持っていた部門があったが, 目下自由化向ってひと しく真剣に努力しつつある。しかし努力するととと，た だちねできるということとは自ら等しいことではない。 たとえばパルプのごときは，外国の 5 割高の值段で原木 を戝入しなければならないし，またソーダのごときは原 料塩を 5〜6 倍の值段で手に入れねばならない。ての問 題は一方的な努力では克服し得ないととは明らかで，こ れが克服には相当の日時を要することすまた明らかであ

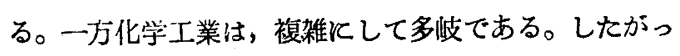
てその対策もまた一様にはいかない。また全ての化学製 品は, 第一次製品から二次製品; 三次製品と変化してい くが，二次製品以後は互いにからみ合って行くことを常 とする。現在無数にある化学製品中，現に好むと好まざ るとを問わず, 自由化されているすのも相当あるが，こ れを扎しなへて自由化するには，原則としてまず第一次 製品からやれという議論は一応もっともなことで, 少な くとも一次留品の值段が国際並みの安定の保証がなて はというのは, 斉しく希望しているところであり, 至極 もっともないい分である。

（ii）私は前項飞貿易自由化飞関する諸要素をいくつ か申し述へた。しかし何れもそうやすやすと進めうるも のとは考兄られない。そこで自由化計画を急いでやろう 上するには，势い、関税改訂に大きな比重を持たせるこ と，実施期を何時にするかということが，重大となって くる。自由化には現在の值段というょり,生産原価の国 際比価が中心になるのは当然であるが，それが近似する か,または当方の方が高い場合, 前 2 項がきわめて重要な 要素となってくる。ところが，日本の化学製品の弣税 は，国際的にみてそう低くはないし，ガット関係は相手 のあることでそうあけていく訳にはいかない。さらにこ こに, 今一つの問題がある。それは関税定率の引き上げ は自由化することを前提としなけれぼならないというこ とであるっつまり関税定率をひきあけて，しかむ自由化 しないということは真と筋の通らない議論だから, それ はやらないという議論が目下通産省幹部に多いのだが, 真に尙っ上きな話なので多分とういうことになるである う。こういう現実的な前提の下に, わが化学製品の自由 化はどういう径路をたどるべきか，またたどるであろう か, 第一次製品から以下眺めてみようと思う。

2. 第一次製品について 総じて, 第一次製品は, 二次, 三次製品よりその自由化は 目下困難な 事情にあ る。しかしカーバイト执よびその誘導品, 塩素敊よでそ の加工品等のごとく，その主原料を外国に仰ぐ必要のな いむのは, 自由化が比較的容易である。また高圧ガスの ことく, 容器およびその輸送の困難なものはこれまた容 易にみえる。しかし同し第一次製品でも, ソーダ，特に ソーダ灰のごときは前述の理由でその自由化には相当の 努力と工夫がいる。ただ，ベンゼン，トルエンについて は，鉄鋼業界の讓歩，つまりベンゼン值段の引き下げを 全化学業界は望んでいる（ベンゼンの製鉄原価中に含ま れる率は，1\%にならないし，製鉄業界は目下上昇景 気にある):この方の関税は目下 $5 \%$ なのだが，ベンゼ ン業界で $25 \%$ への引き上けを希望している。一般化 
学工業ト界ではその影幚するとてろ，きわめて大きいの で，0を希望しているが，何事でも慣習を無視する訳に はいかない。自由化て伴なって，10\% とするくらいが おちであろう。今化学工業第一次製品の国際比価を，米 国および西ドイツのそれと，各工場オンレール值段（円 (t) で比較してみると表 2 のごとくである。

\section{表 2}

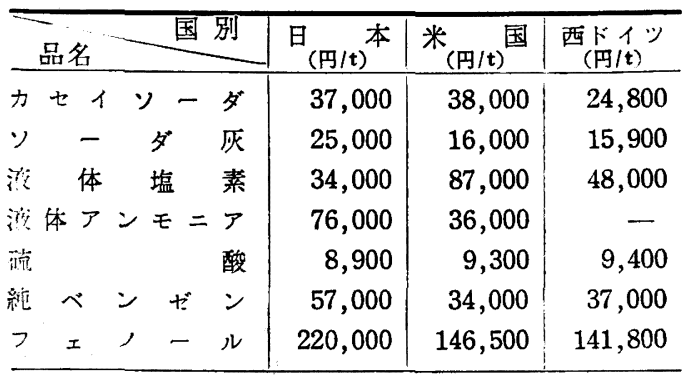

目下化学製品中，関税秄よびその貿易自由化が最も問 题となっているのは，第一次製品中，ソーダ，・ーダ死 さよびハンゼンであるが，怙そらく後者については，関 税 10\% として近い将来炑自由化されることであ万う。 トルエン，キシレンについても概ね同様なことであろ うっフェノールKついては，当事者は現行関税 $20 \%$ を 4C\% にと望んでいるが，拓そらくそれは事実上䁈理な ことで $25 \%$ ぐらいに落着くのではないだろうかおっ 上もこの方は近い将来，自由化という訳にはいかず，若 干の日時を要することであろう(この種のもいは石油

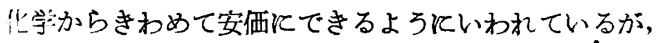

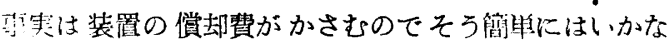
い)。ソーダ死は最もむつかしいものの一つで, 目下国際 比佃 150 160\% であるが，アンモニアの自給ができ， 三れが板についた場合，すなわち 2,3 年後には，現行 $2 \Xi \%$ 関税として自由化できるようになるであろう。電
解ソーダについては，㙁素の安くしかる需要激増の点を 考えあわすと，そう問題はないであろう。カーバィト， 硫酸とついても，そう問題はないと思われる。格とらく 現行据置きとなるであろう。

3. 第二次製品について 前項国際比価の示すその 比価の高いベンゼン，フェノールに負うところ多い染 料，塗料製品は，業界不断の努力活かかからず，なか なか追いつけないでいるが(むっとあ染料火ついては， 各国とも儲らないで弱っているのである), 塩素化合物, 無機薬品の多くは，招括むね自由化の体制がてきつつお るし，洗剤とついても同様である。ただし無機薬品であ バリウム塩類，鉛，要鉛化合物のごとく，原料を外国の 金属または鉱石に負うあのはなかなかむつかしい。また 特殊の活性炭についても当分若干関税を上けてむむつか しいであろう。カーバイト誘導品，および主な合成薣脂 業界は，現行関税で括招むね自由化付耐えるに至るであ ろう。硫安，尿素は何れも原料ガス化が，天然ガスまた は石油ガス化によって進行中であるが，これが両 3 年中 飞完了すれは，石灰徸素，過りン酸石灰と共飞，国際比 価が自由化に耐えるに至るであろう。

\section{IV.む す び}

以上若干の私見を加えてあるが，要するとてろ，日本 の化学工業各部門は，目下着々と産業家の本命として自 由化に対処する準備を進めている。その多くは 5 年を待 たずして行なわれ，遅くもその対策よろしきをうれば， この辺でできるように思われる。しかしながら，業界は これと同時に，これと並行して，関税の政訂（緊急条 項, タリフコーター制, 弾力関税些施を容易ならしめる 立法, 特に祭急条项実施を急ぐ), カルテルの許可, 金利: 引き下けへの努力は, 当然のモラルとして, 実施される ことを望み，から期待しているのである。

\section{合本用ファイルのお知らせ}

本誌保存用のファイル（12冊緅 1 ケ年分）が出来て怙ります。ご希望の方は代金を添 觉てお申込み下さい。

$\begin{array}{lll}\text { 定 } & \text { 価 } & 1 \text { 部 } \\ \text { 送 } & \text { 料 } 24 \text { 円 (1 部增すごとに16円) }\end{array}$

